\begin{tabular}{lll}
\hline PREGLEDNI & UDK: $37.091 .3: 81: 82.0-7$ & Primljen: 22.2 .2021$. \\
RAD & DOI: $10.22210 /$ strjez/50-2/5 & Prihvaćen: 20.7 .2021$.
\end{tabular}

\title{
Humor u nastavi stranoga jezika
}

\author{
Marina Mrazovac \\ mrazovac.marina@gmail.com \\ Glazbena škola Ivana Matetića Ronjgova Rijeka
}

\begin{abstract}
$\mathrm{U}$ ovome radu nudi se prikaz relevantne literature i istraživanja koja se bave primjenom humora u nastavi stranoga jezika. Humor je relativno kompleksna pojava koju je vrlo teško jednoznačno definirati budući da se pojavljuje u različitim oblicima i situacijama te ovisi o individualnim karakteristikama pojedinaca koji ga koriste u pisanome ili usmenome diskursu. Kada je riječ o primjeni humora u nastavi stranoga jezika, rezultati istraživanja uvelike ukazuju na njegove mnogobrojne pozitivne učinke na učenike i nastavni proces, od unaprjeđenja razredne atmosfere i komunikacije, do raznih jezičnih doprinosa. Međutim, implementacija humora u nastavu ne treba se shvatiti olako. Način i željeni ishod korištenja humora u nastavi moraju biti dobro osmišljeni kako bi se izbjegli potencijalni neželjeni rezultati. Ako mu se pristupi na pravilan način, humor svakako može biti koristan sudionik svakoga nastavnog procesa.
\end{abstract}

Ključne riječi: humor, nastavni proces, nastava stranoga jezika, jezična igra.

\section{UVOD}

Uspješnost nastavnoga procesa vrlo često ovisi o brojnim parametrima, među kojima su svakako i sudionici toga procesa, odnosno nastavnici i učenici. Na njihove uloge u nastavi također utječe niz faktora, od kojih neki prolaze kroz svakodnevnu nastavu gotovo nezamijećeni, iako zapravo imaju izuzetno veliku ulogu $u$ kvaliteti provođenja nastave te u izgradnji odnosa između učenika i nastavnika. Jedan od takvih elemenata, koji se vrlo 
često ostavlja na odabir i volju samome nastavniku, sukladno njegovim ili njezinim osobnim preferencijama, jest humor. Osim što se u razredu vrlo često koristi kao sredstvo za opuštanje atmosfere, humor može poslužiti i kao vrlo učinkovit element u poučavanju nastavnih sadržaja. Nastava stranoga jezika ${ }^{1}$ može biti stresna za mnoge učenike, s obzirom na to da od njih zahtijeva aktivno verbalno izražavanje na uglavnom nepoznatome jeziku, kojim su više ili manje uspješno ovladali, a koji mogu bolje savladati samo ako ga nastave koristiti, što učenike potencijalno dovodi u situaciju začaranoga kruga stresa, u kojoj je učenje gotovo u potpunosti onemogućeno, ili barem ozbiljno otežano. Takve situacije mogu se vrlo uspješno riješiti uvođenjem humora koji, osim što će svakako ublažiti stresnu atmosferu u razredu, može poslužiti između ostaloga i kao odličan primjer raznih jezičnih konstrukcija. Budući da brojna istraživanja pokazuju kako humor ima višestruke dobrobiti za nastavni proces, u ovome će preglednome radu ukratko biti prikazani neki od učinaka koje humor ima u nastavi, s posebnim naglaskom na nastavu stranoga jezika.

\section{HUMOR}

Prije definiranja uloge humora u nastavnome procesu, bitno je definirati sam pojam. Dio problematike značenja koncepta 'humor' leži i u njegovoj gotovo neodvojivoj konceptualnoj poveznici s pojmovima 'smijeh' i 'smiješno', kojima se, kako navodi Zergollern-Miletić (2021) često i zamjenjuje, međutim kako Matijević (1994: 11) zaključuje dodajući u spomenuti međuodnos i termin 'komika', iako postoje sadržajne poveznice, ne može se govoriti o istoznačnicama. Da bi se tako kompleksan fenomen mogao postaviti u određeni jednoznačan okvir, moraju se sagledati sve njegove sastavnice i karakteristike. Stoga ne iznenađuje kako znanstvenici i stručnjaci koji proučavaju humor iz različitih aspekata i unutar raznih domena nude i različite definicije pojma. Tako je humor u širemu smislu definiran kao kvaliteta, odnosno sposobnost pojedinca da bude duhovit i nasmije drugu osobu (Lovorn i Holaway, 2015; Ruch, 1998), pri čemu je bitno istaknuti i subjektivni aspekt humora, zbog čega osobe ne moraju nužno percipirati humor na jednak način (Bakar i Kumar, 2019; Berk, 2002). Ziyaeemehr, Kumar, i Abdullah (2011: 111) nadalje navode kako je humor (socio)

\footnotetext{
${ }^{1} \mathrm{U}$ ovome radu termin strani jezik podrazumijeva bilo koji jezik koji učeniku nije materinski i koji se poučava i usvaja u institucionaliziranome kontekstu unutar kojega se odvija jasno definirani nastavni proces.
} 
lingvistički i sociokulturološki fenomen koji ima širok raspon obrazovnih kvaliteta. Razna istraživanja ukazuju na to da humor pozitivno utječe na nastavni proces (npr. Askildson, 2005; Bieg, Grassinger i Dresel, 2017; Neff i Rucynski, 2017), međutim, da bi se u tome kontekstu moglo govoriti o ulozi humora, nužno je razmotriti njegovu upotrebu kroz parametre koje čine nastavnik, učenici, nastavni predmet, učionica te povratna informacija učenika (Bakar, Kumar, 2019: 16), budući da o njima ovisi implementacija humora u nastavu stranoga jezika.

\subsection{Teorije humora}

Kako bi se prikazao tijek razumijevanja i procesuiranja humora, razvijene su različite teorije koje uzimaju u obzir mnoge odrednice toga fenomena. Morreall (2012) nudi pregled definiranja humora kroz tri teorije, odnosno kroz teoriju agresivnosti ili superiornosti, prema kojoj humor nastaje kao rezultat osjećaja nadmoći nad drugim subjektom ili prošlim verzijama nas samih, teoriju opuštanja, prema kojoj je humor nusproizvod otpuštanja nervoze te kroz teoriju inkongruentnosti ili nesklada, koja humor vidi kao rezultat situacije čiji je ishod u neskladu s očekivanim razrješenjem. Zergollern-Miletić (2021) također spominje navedene tri teorije kao osnovne teorije koje se u novije vrijeme najčešće koriste, ali osim njih pruža i izuzetno detaljan povijesni pregled razvoja najpoznatijih teorija i pristupa humoru i ranije navedenim srodnim terminima, između ostalih, krenuvši od Platona pa sve do suvremenih teorijskih pristupa. Matijević (1994) spominje još i teoriju ambivalencije ili oscilacija, prema kojoj je humor rezultat nespojivih emocija koje pojedinac istovremeno osjeća te teoriju neprikladnosti, koja podrazumijeva nepodudaranje određenih dijelova neke situacije, pri čemu je ključno vidjeti 'poznato' u novim odnosima, što rezultira smiješnim ishodom. Osim navedenih teorija, spominje se i teorija koja pretpostavlja da se humor razvio iz igre te je jedina, kako Morreall (2012) navodi, koja humor dovodi u korelaciju s izrazima lica, govorom tijela i zvukom smijeha. U novije se vrijeme, međutim, humor najčešće objašnjava i definira kroz teoriju nesklada.

Da bi poruka bila duhovita, primatelj mora u njoj uočiti nesklad u odnosu na očekivani ishod unutar postojećega konteksta poruke. Međutim, ako je inkongruentnost preapsurdna ili presložena da bi se razumjela, može dovesti do toga da se ni sama šala uopće ne shvati ili čak ni ne percipira (Wanzer, Frymier i Irwin, 2010). Berk (2002) ističe nesklad kao bitnu strukturu humora i definira ga kroz element očekivana sadržaja, najčešće unutar 
ozbiljna konteksta, u sklopu kojega se zatim razvija element neočekivana zaokreta i duhovita ishoda. Attardo i Raskin (1991) u svojoj općoj teoriji verbalnoga humora navode kako je humor rezultat rješavanja nesklada. Prema toj teoriji, u kontekstu unutar kojega se nađu dva oprečna ili neočekivana elementa, dolazi do inkongruentnosti koja se mora barem djelomično razriješiti kako bi se oprečnost smatrala duhovitom. Opća teorija verbalnoga humora modelira proizvodnju humora kroz šest hijerarhijski rangiranih izvora znanja: na najnižoj razini jest jezik (eng. language), u smislu sustava unutar kojega se stvara duhovita izjava, zatim slijedi narativna strategija (eng. narrative strategy), što podrazumijeva vrstu ili žanr humora (vic, zagonetka i sl.). Nakon žanra humora slijedi meta (eng. target), koja može uključivati bilo kojeg pojedinca ili grupu ljudi koji su predmet ismijavanja. Pritom se ističe i kako je ta razina jedina koja ne mora uvijek biti uključena u proizvodnju humora budući da neke šale nemaju jasno određenu metu. Kontekst (eng. situation), kao sljedeća razina, uključuje sudionike i okolnosti unutar kojih se razvija određena humoristična situacija. Razina logičkoga mehanizma (eng. logical mechanism) podrazumijeva način stvaranja humora koji omogućava razrješavanje nesklada. Naposljetku dolazi razina oprečnosti scenarija (eng. script oppositions), na kojoj se interpretira sadržaj šale. Šala zadržava dvoznačnost scenarija do trenutka kada poanta koja povezuje dvije oprečnosti razriješi inkongruentnost, što u konačnici rezultira humorističnim ishodom.

Stavljajući humor u nastavni kontekst, prema teoriji procesuiranja edukativnoga humora, koju su postavili Wanzer i sur. (2010), humor koji je povezan s nastavnim sadržajem pozitivno će utjecati na učenike, povećavajući njihovu motivaciju i sposobnost za procesuiranje informacija, dok će neprimjerene vrste humora, primjerice uvredljive i omalovažavajuće šale, učenike demotivirati i potencijalno čak odvratiti od materijala koji se obrađuje. Iz toga je razloga vrlo bitno jasno definirati ne samo što točno humor jest nego i u kojim se oblicima pojavljuje, kako bi njegova implementacija u nastavni proces bila što uspješnija i korisnija.

\subsection{Klasifikacija humora}

Imajući na umu moguće pozitivne i negativne utjecaje humora na učenike, prije nego se uvede u nastavni proces, bitno je definirati koja će se vrsta humora i kako primijeniti u praksi. Iako čak ni klasifikacija humora nije bez mane, budući da se u prirodnome, svakodnevnome razgovoru nerijetko miješaju različite vrste humora, što otežava sistematizaciju na jasno odre- 
đene, 'čiste’ kategorije (Bell, 2009; Reddington, 2015), najčešće se spominju i koriste kategorije šale, duhovite priče, parodije, doskočice, igre riječima, ironija, preuveličavanja i sl. (Bell, 2011; Norrick, 2003; Reddington, 2015; Reddington i Waring, 2015; Wagner i Urios-Aparisi, 2011). Kategorizacija humora koju navode Petraki i Nguyen, (2016) primjenjivija je u nastavnome kontekstu, a temeljena je na sljedećim kriterijima: vrste humora (eng. types) definirane prema određenoj kategoriji (šala, doskočica i sl.), subjekti (eng. subjects) prema kojima je humor usmjeren (npr. nastavnik, učenik), značajnost (eng. relevance) u odnosu na nastavni proces, tematiku i sl. te stupnjevi pripremljenosti humora (eng. levels of preparation), koji definiraju kako humor nastaje, odnosno radi li se o spontanu korištenju humora ili je on unaprijed pripremljen. Schmitz (2002) predlaže kategorizaciju humora koji se koristi u nastavnome procesu na univerzalni humor, koji se oslanja na kontekst i opću kulturu, zatim na kulturološki humor te na jezični humor, koji se oslanja na jezične karakteristike određenoga jezika. Također sugerira i način primjene svake od navedenih grupa humora, pri čemu navodi kako je univerzalni humor prikladan za primjenu kod učenika svih jezičnih razina, dok napominje da je jezični humor najučinkovitiji ako se uvede u nastavu jezika učenicima koji su samostalni govornici jezika ili su već na naprednoj razini znanja jezika. Bell (2009), s druge strane, smatra da je jezična kreativnost prisutna u raznim oblicima i stoga može biti dostupna učenicima na svim jezičnim razinama. Nadalje, upozorava na međuovisnost razumijevanja univerzalnoga humora i situacija unutar kojih nastaje, bez obzira na njegovu povezanost sa svakodnevnim događajima i ljudskim ponašanjima. Što se tiče kulturološki uvjetovanoga humora, Schmitz (2002) navodi kako se neki oblici te vrste humora mogu prakticirati tek s učenicima koji su samostalni korisnici jezika i naprednim učenicima, što podupiru i Neff i Rucynski (2017), koji smatraju da učenici moraju posjedovati određena znanja i jezične vještine kako bi mogli uspješno razumjeti kulturološke implikacije. Deneire (1995) također smatra nužnim da učenici razviju određenu razinu kulturološke kompetencije i razumijevanja ciljane kulture budući da su u humoru skrivena razna kulturološka značenja. Bell (2009) upozorava na činjenicu da se neke vrste humora ne prihvaćaju jednako uspješno u svim kulturama te pritom napominje kako kultura nije prisutna samo u sadržaju samoga humoristična izričaja, nego i u kontekstu te načinu izražavanja i izvanjezičnom značenju korištenih riječi i izraza.

Kada se pak promatra u okviru poučavanja i usvajanja stranoga jezika, humor se u literaturi vrlo često povezuje s konceptima jezične igre (engl. language play) te kreativnoga i duhovitoga pristupa korištenju jezika (Red- 
dington, 2015). Jezična igra podrazumijeva bilo koji oblik neozbilina korištenja jezika u svrhu zabave, a ne isključivo u svrhu prijenosa informacije te se može odvijati na fonološkoj, morfosintaktičkoj, semantičkoj ili pragmatičkoj razini (Bell i Pomerantz, 2016: ix). Jezična se igra također može manifestirati kao igra $s$ jezikom (primjerice, stvaranje novih riječi i jezičnih dosjetki) ili kao igra $u$ jeziku (primjerice, korištenje jezika kako bi se ispričala duhovita anegdota, osmislila nestvarna priča, i sl.) (Bell, 2012; Tong i Tsung, 2020). Bell (2012), međutim, napominje kako jezična igra i humor nisu istoznačni pojmovi, objašnjavajući da iako je većina primjera jezične igre duhovita karaktera, duhovitost nije nužno karakteristika svih primjera takva korištenja jezika, dok humor uvijek sadrži odrednicu duhovitosti.

\section{HUMOR U NASTAVI STRANOGA JEZIKA}

Nastavni proces ponekad može djelovati zamorno i demotivirajuće, kako za učenike, tako i za nastavnike, osobito kada je riječ o nastavi koju su učenici primorani pohađati, kao što je slučaj u obveznome obrazovanju ili kada nastavnik mora predavati gradivo koje je odavno prestalo biti novo i izazovno za obradu. U takvim situacijama, čak i da se ne učine nikakve promjene u metodičkome pristupu ili samome gradivu koje će se obraditi, uključivanje humora u izlaganje zbog njegova izuzetno afektivna učinka (Bell i Pomerantz, 2016; Deneire, 1995) može uvelike pomoći učenicima i nastavnicima. Osim toga, Wagner i Urios-Aparisi (2011) ističu kako humor kao dio svakodnevnoga komunikacijskog procesa u nastavu unosi konkretan sadržaj i potiče razvijanje interkulturalnosti. Ziyaeemehr i sur. (2011) smatraju da humor ima svoje mjesto u nastavi stranoga jezika budući da, između ostaloga, može biti implementiran i u poučavanje svih četiriju jezičnih vještina te upozoravaju kako izbjegavanje humora u nastavi može učenike zakinuti za jezične i kulturološke specifičnosti koje je vrlo teško pronaći u nehumorističnu sadržaju.

\subsection{Uloga humora $\mathrm{i}$ jezične igre u nastavi stranoga jezika}

Humor ima mnoge pozitivne učinke na nastavni proces, bez obzira na to o kojemu je predmetu riječ, međutim, u nastavi stranoga jezika, njegova je uloga značajna ne samo za samo odvijanje nastavnoga procesa, odnos između nastavnika i učenika, društveni i kognitivni razvoj te za formiranje razrednoga identiteta (Tong i Tsung, 2020), nego i za proces usvajanja stranoga jezika i ciljane kulture (Askildson, 2005), stavljanje fokusa na formu, razvijanje sociolingvističkih kompetencija i stvaranje razredne sredine koja 
potiče suradnju (Reddington, 2015). Osim toga, humor vrlo često uspješno djeluje kao element ublažavanja neugodnih situacija u razredu. Učenici koji se u svojemu okruženju osjećaju sigurnima da se ponašaju slobodno i koriste jezikom bez straha od osuđivanja ili negativnih reakcija na drugačije, neočekivano ponašanje i proizvedeni jezik, što Bell i Pomerantz (2016) definiraju kao sigurni prostor (engl. safe house), primjenom jezične igre neizbježno će otkrivati jezične obrasce i pravila i slobodno eksperimentirati $\mathrm{s}$ jezikom te im tako korištenje jezične igre može olakšati proces usvajanja stranoga jezika (Bell, 2005; Bell i Pomerantz, 2016; Bushnell, 2009; Cook, 2000). Iako jezična igra ne mora nužno biti potrebna za usvajanje stranoga jezika, Tarone (2000) navodi kako je njezin utjecaj na učenje vidljiv u smanjenju anksioznosti, boljemu pamćenju jezika, stvaranju mogućnosti za učenike da eksperimentiraju s različitim jezičnim varijantama te u destabilizaciji međujezika.

Budući da su humoristične interakcije dio svakodnevne slobodne komunikacije, korištenjem humora u nastavi stranoga jezika učenicima se može predočiti ne samo niz jezičnih, kulturoloških i pragmatičnih značajki nego i izuzetno bitni diskursni uzorci (Askildson, 2005). Iako humor koji se koristi u nastavi ne mora nužno biti identičan humoru koji se koristi u svakodnevnoj interakciji (Deneire, 1995), priroda nastavnoga procesa je takva da učenicima nudi mogućnost slobodna istraživanja i eksperimentiranja s jezikom te značenjem i razumijevanjem humora i implicitno prisutne kulture, kako bi se osjećali što kompetentnijima u budućoj interakciji s govornicima izvan učionice (Bell, 2009; Neff i Rucynski, 2017; Schmitz, 2002).

\subsection{Implementacija humora i jezične igre u nastavni proces}

Prema definiciji koju nude Wagner i Urios-Aparisi (2011), humor u učionici podrazumijeva lingvističko ili nelingvističko djelovanje nastavnika ili učenika. Nastavnici koji se odluče inkorporirati humor u svoju nastavu, trebali bi razmisliti između ostaloga i o vrsti humora koji će upotrijebiti, na koji način će se humor implementirati, kao i o kulturološkim implikacijama humora, ali i o kulturnim i osobnim sličnostima i razlikama između učenika te učenika i nastavnika. Navedeni autori također napominju kako prilikom implementacije humora u nastavni proces treba uzeti u obzir i sposobnost učenika za kognitivno procesuiranje humora te povezanost humora s učenjem i ishodima učenja.

Rezultati Askildsonova istraživanja (2005) u kojemu je sudjelovalo 236 učenika i 11 nastavnika pokazuju kako je humor važan dio procesa uče- 
nja. Većina sudionika smatrala je da je humor bitan za stvaranje pozitivne atmosfere za učenje, smanjenje anksioznosti, povećani interes učenika, kao i bolju pristupačnost nastavnika. Obje su grupe primijetile i da je upotreba humora u nastavi rezultirala boljim usvajanjem ciljanoga jezika i kulture.

Ziyaeemehr i sur. (2011) proveli su istraživanje koje je pokazalo da humor ima motivirajuću i opuštajuću ulogu u učionici, da pomaže kod zadržavanja pažnje i poticanja aktivnosti učenika te da olakšava proces usvajanja i zadržavanja naučenoga gradiva.

Lovorn i Holaway (2015) ispitivali su stavove nastavnika prema ulozi humora u nastavi te su pokazali da nastavnici smatraju kako humor ima vrlo važnu afektivnu ulogu budući da, između ostaloga, pomaže učenicima da zadrže pažnju i motivaciju, stvara pozitivnu razrednu atmosferu te potiče učenike na suradnju i komunikaciju. Ispitanici su također istaknuli da humor pomaže učenicima u usvajanju gradiva i promiče korištenje sposobnosti promišljanja višega reda. Međutim, napomenuli su kako humor može imati i negativne utjecaje u nastavi, što je najčešće vidljivo u problemima s reguliranjem razredne dinamike, zadržavanjem fokusa na nastavnome materijalu te potencijalno neozbiljnu pristupu učenika sadržaju koji se obrađuje.

Istraživanje koje su proveli Petraki i Nguyen (2016) pokazalo je da humor ima važnu ulogu u nastavi engleskoga kao stranoga jezika čak i u kontekstu, kako se općenito smatra, strogih i autoritativnih vijetnamskih sveučilišnih učionica. Pozitivne afektivne i kognitivne uloge humora vidljive su, između ostaloga, u stvaranju opuštene razredne atmosfere što je doprinijelo većoj motivaciji i interakciji studenata koji su bolje usvajali gradivo i bili u bliskijim odnosima s nastavnicima.

Bieg, Grassinger i Dresel (2017) upozoravaju na pristup humoru u kontekstu učionice jer je njihovo istraživanje pokazalo kako humor kao izolirani fenomen neće nužno kod učenika potaknuti pozitivne emocije. U svojemu istraživanju navode kako humor koji nije povezan s nastavnim materijalom ne donosi korisne informacije te ga učenici mogu smatrati gubljenjem vremena i osjećati se nelagodno u nastavnome procesu koji sadrži humoristične elemente takve vrste.

Bakar i Kumar (2019) proučavali su upotrebu humora u nastavi petoro nagrađivanih sveučilišnih nastavnika. Njihovo je istraživanje pokazalo da su nastavnici koristili humor na vrlo strateški način, prije svega u svrhu poučavanja. Primjenjivali su i spontani i unaprijed isplanirani humor, čija je svrha u obama slučajevima bila olakšavanje i unaprjeđenje procesa učenja te zadržavanje pažnje učenika. 
Implementacija humora i jezične igre u nastavi stranoga jezika ne ovisi samo o elementima vezanima uz fenomen humora, odnosno o humorističnome pristupu korištenju jezika, nego i o kontekstu i sociološkim, kulturološkim i socioekonomskim karakteristikama sudionika u nastavnome procesu. Prije svega, treba uzeti u obzir činjenicu da nemaju svi sudionici jednak smisao za humor, o čemu ovisi i njegova uloga u izgradnji odnosa između nastavnika i učenika (Van Praag, Stevens i Van Houtte, 2017). Isti autori skreću pažnju i na uloge koje su dodijeljene nastavnicima i učenicima, a društveno su jasno definirane u odnosima moći unutar konteksta učionice. Osim toga što su neki nastavnici i učenici više skloni koristiti humor od drugih kao rezultat njihovih osobnosti (Waring, 2013), u nekim je slučajevima (ne)korištenje humora u nastavi stranoga jezika uvjetovano kulturološkim percepcijama i onime što se smatra više ili manje prikladnim u nastavnome procesu (npr. Lovorn i Holaway, 2015; Neff i Rucynski, 2017; Tong i Tsung, 2020).

Zergollern-Miletić (2021: 137-142) navodi istraživanje provedeno na 115 studenata i studentica Učiteljskog studija s engleskim jezikom u Zagrebu u akademskoj godini 2016./2017., koje je pokazalo da studenti općenito imaju vrlo pozitivan stav prema humoru. Osim što smatraju da je humor važan $u$ ljudskom životu, vide ga i kao bitan element u učionici, pri čemu samo $4 \%$ studenata smatra da se $\mathrm{s}$ humorom 'ne smije pretjerivati'. Nešto manje od polovice ispitanika izjavilo je da su kao učenici imali negativna iskustva u razredu navodeći kao najčešće uzroke sarkazam nastavnika, neprimjerene šale te ismijavanje učenika, što potvrđuje važnost uloge nastavnika prilikom uvođenja humora u nastavni proces. Većina ispitanika također je izjavila kako u vlastitim budućim učionicama namjeravaju kombinirati ozbiljnost i humor kako bi održali ravnotežu između rada i zabave, naglašavajući tako edukativni i autoritativni aspekt nastavnoga procesa koji bi mogao biti narušen prevelikom količinom opuštenosti i zabave.

Osim svega ranije navedenoga, ne treba zanemariti ni postojeću mikrokulturu unutar razreda u kojemu se odvija nastava stranoga jezika. Naime, mikrokulture nastavnika i učenika, pa čak i učenika međusobno, mogu se značajno razlikovati. Primjerice, unutar istoga razreda često se nalaze učenici različitih nacionalnosti, religija, socijalnoga statusa i sl., što su itekako bitni parametri koje treba imati na umu ako nastavnik odluči koristiti humor u sklopu nastave, ne nužno zbog parametara kao takvih, nego zbog toga što oni indirektno mogu utjecati na preferencije u vrstama humora, što pak može rezultirati nerazumijevanjem između nastavnika i učenika. Istraživanje koje su proveli Van Praag i sur. (2017) pokazalo je kako učeni- 
ci različitoga socioekonomskog statusa ne reagiraju jednako na iste vrste humora. Učenici većinom boljega socioekonomskog statusa pozitivnije su reagirali na inteligentne šale povezane s nastavnim sadržajem od učenika većinom lošijega socioekonomskog statusa, koji su se pak često koristili vrstom humora na koji nastavnici nisu uvijek znali kako reagirati. Također, humor koji je korišten s učenicima boljega socioekonomskog statusa bio je više politički korektan, temeljen na znanju i manje osoban, u usporedbi s vrlo izravnom, osobnom vrstom humora koji je korišten u nastavi koju su pohađali učenici lošijega socioekonomskog statusa.

\section{ZAKLJUČAK}

Iako razna istraživanja neupitno pokazuju da humor ima vrlo vrijednu ulogu u nastavi, njegova implementacija nikako ne bi smjela biti provedena bez prethodne analize profila učenika i njihovih potreba. Ako se uvede $u$ nastavu na prikladan način, humor može biti višestruko koristan. Imajući na umu općeprihvaćeno nepisano pravilo tradicionalnoga obrazovnog sustava u kojemu se u praksi greške još uvijek penaliziraju te se na njih gleda kao na problem, umjesto da služe isključivo kao smjernice prema prostoru za napredak, svaki neuspjeh u procesu usvajanja stranoga jezika, ma koliko on prirodan bio, kod učenika kumulativno potiče sve veću dozu anksioznosti i otpora prema materiji te u konačnici i (uspješnome) korištenju jezika, što bi trebao biti glavni cilj nastave stranoga jezika. Kada bi nastavnici praktičnome dijelu nastavnoga procesa, prije svega poučavanju jezika i jezičnim intervencijama kod učenika, pristupili s dozom humora te tako stvorili opuštenu atmosferu u kojoj vlada minimalna anksioznost, velike su šanse da bi učenici bili puno prijemčiviji ne samo materiji koja se poučava nego i predmetu i nastavnome procesu uopće. Osim što ima izuzetno bitnu afektivnu ulogu, primjeren humor služi i kao pokretač pozitivne i bliske razredne atmosfere i odnosa između nastavnika i učenika. U nastavi stranoga jezika njegova je vrijednost dodatno povećana brojnim jezičnim doprinosima ne samo u vidu jezične igre, nego i u obliku elemenata i specifičnosti ciljanoga jezika i kulture s kojima se učenici u nehumorističnome jeziku možda ne bi uopće imali prilike susresti. Uzevši u obzir samo neke od mnogih pozitivnih aspekata humora u nastavi stranoga jezika, bez obzira na činjenicu da njegova implementacija zapravo najviše, ako ne i isključivo, ovisi o predmetnome nastavniku i njegovim ili njezinim osobnim afinitetima, može se zaključiti da bi humor svakako trebao imati svoje mjesto u razredu i nastavi stranoga jezika. 


\section{LITERATURA}

Alsop, S. (2015) The 'humour' element in engineering lectures across cultures: An approach to pragmatic annotation. Language and Computers, 79, 337-361.

Attardo, S., Raskin, V. (1991) Script theory revis(it)ed: joke similarity and joke representation model. Humor 4-3/4, 293-347.

Askildson, L. (2005) Effects of humor in the language classroom: humor as a pedagogical tool in theory and practice. Journal of Second Language Acquisition and Teaching, Vol 12, 45-61.

Bakar, F., Kumar, V. (2019) The use of humour in teaching and learning in higher education classrooms: Lecturers' perspectives. Journal of English for Academic Purposes, 40, 15-25.

Bell, N. (2005) Exploring L2 language play as an aid to SLL: A case study of humor in NS-NNS interaction. Applied Linguistics, 26 (2), 192-218.

Bell, N. (2009) Learning about and through humor in the second language classroom. Language Teaching Research, 13,3, 241-258.

Bell, N. (2011) Humor scholarship and TESOL: Applying findings and establishing a research agenda. TESOL Quarterly, 45 (1), 134-159.

Bell, N. (2012) Comparing Playful and Nonplayful Incidental Attention to Form. Language Learning, 62 (1), 236-265.

Bell, N., Pomerantz, A. (2016) Humor in the classroom: A guide for language teachers and educational researchers. New York, N.Y: Routledge.

Berk, R. A. (2002) Humor as an instructional defibrillator: evidence-based techniques in teaching and assessment. Sterling, Virginia: Stylus Publishing, LCC.

Bieg, S., Grassinger, R., Dresel, M. (2017) Humor as a magic bullet? Associations of different teacher humor types with student emotions. Learning and Individual Differences, 56, 24 33.

Bushnell, C. (2009) "Lego my keego!": An analysis of language play in a beginning Japanese as a foreign language classroom. Applied Linguistics, 30 (1), 49-69.

Cook, G. (2000) Language play, language learning. Oxford: Oxford University Press.

Deneire, M. (1995) Humor and language teaching. Humor, 8-3, 285-298.

Lovorn, M., Holaway, C. (2015) Teachers' perceptions of humour as a classroom teaching, interaction, and management tool. European Journal of Humour Research, 3 (4), 24-35.

Matijević, M. (1994) Humor u nastavi: pedagoška i metodička analiza. Zagreb: UNA-MTV.

Morreall, J. (2012) Philosophy of Humor. Stanford Encyclopedia of Philosophy. https://plato. stanford.edu/entries/humor/ (31. 10. 2020.)

Neff, P., Rucynski, J. (2017) Japanese perceptions of humor in the English language classroom. Humor, 30-3, 279-301.

Norrick, N. R. (2003) Issues in conversational joking. Journal of Pragmatics, 35 (9), 1333-1359.

Petraki, E., Nguyen, H. H. P. (2016) Do Asian EFL teachers use humor in the classroom? A case study of Vietnamese EFL university teachers. System, 61, 98-109.

Reddington, E. (2015) Humor and Play in Language Classroom Interaction: A Review of the Literature. Working Papers in TESOL \& Applied Linguistics, 15 (2), 22-38.

Reddington, E., Waring, H. Z. (2015) Understanding the Sequential Resources for Doing Humor in the Language Classroom. Humor, 28 (1), 1-23.

Ruch, W. (1998) The sense of humor. Berlin: Mouton de Gruyter.

Schmitz, J. R. (2002) Humor as a pedagogical tool in foreign language and translation courses. Humor, 15-1, 89-113. 
Tong, P., Tsung, L. (2020) Humour strategies in teaching Chinese as second language classrooms. System, 91, 1-15.

Praag, L. V., Stevens, P. A.J., Van Houtte, M. (2017) How humor makes or breaks studentteacher relationships: A classroom ethnography in Belgium. Teaching and Teacher Education, 66, 393-401.

Wagner, M., Urios-Aparisi, E. (2011) The use of humor in the foreign language classroom: Funny and effective? Humor, 24-4, 399-434.

Wanzer, M. B., Frymier, A. B., Irwin, J. (2010) An Explanation of the Relationship between Instructor Humor and Student Learning: Instructional Humor Processing Theory. Communication Education, 59 (1), 1-18.

Waring, H. Z. (2013) Doing being playful in the second language classroom. Applied

Linguistics, 24 (2), 191-210.

Zergollern-Miletić, L. (2021) Humor, smijeh, misao, jezik. Zagreb: Hrvatska sveučilišna naklada.

Ziyaeemehr, A., Kumar, V., Abdullah, M. (2011) Use and non-use of humor in academic ESL classrooms. English Language Teaching, 4 (3), 111-119.

\title{
Humor in the foreign language classroom
}

\author{
Marina Mrazovac \\ mrazovac.marina@gmail.com \\ Glazbena škola Ivana Matetića Ronjgova Rijeka
}

This paper offers an overview of the literature and research relevant to the application of humor in the foreign language classroom. Humor is a rather complex phenomenon which can be challenging to define unambiguously, since it appears in various forms and situations and is dependent on the individual characteristics of the person using it in written or spoken discourse. When talking about the application of humor in the foreign language classroom, relevant research suggests that it can be highly beneficial to both the students and the educational process, its positive effects ranging from improving classroom atmosphere and communication to having various linguistic benefits. Its implementation in the teaching process, however, should not be taken lightly. In order to avoid potential negative outcomes of using humor in a lesson, it is crucial to clearly define and conceptualize the planned outcomes, as well as how humor will be used. If applied appropriately, humor can definitely be a useful participant in every teaching process.

Key words: humor, teaching process, foreign language classroom, language play. 